\title{
Are There Non-linear Relationships between Ownership Structure and Operational Performance? Empirical Evidence from Portuguese SMEs Using Dynamic Panel Data
}

\author{
António Pedro Soares Pinto ${ }^{1} \&$ Mário Gomes Augusto ${ }^{2}$ \\ ${ }^{1}$ Polytechnic Institute of Viseu, Campus Politécnico, Viseu, Portugal \\ ${ }^{2}$ School of Economics and Institute of Systems and Robotics, University of Coimbra, Coimbra, Portugal \\ Correspondence: Mário Gomes Augusto, School of Economics and Institute of Systems and Robotics, University of \\ Coimbra, Avenida Dias da Silva, 165, 3004-512 Coimbra, Portugal. Tel: 351-2-3979-0544. E-mail: \\ maugusto@fe.uc.pt
}

Received: April 2, 2014

doi:10.5430/ijba.v5n3p162

\author{
Accepted: April 30, 2014 \\ Online Published: May 10, 2014 \\ URL: http://dx.doi.org/10.5430/ijba.v5n3p162
}

\begin{abstract}
This paper analyzes the causal relationship between the ownership concentration, insider ownership and operational performance using a sample of 4.163 Portuguese SMEs and panel data models. The main results show an endogenous and dynamic relationship between those variables. The quadratic specification established between ownership concentration and operational profitability suggests that for low levels of control rights the expropriation hypothesis prevails and for high levels the supervision hypothesis prevails. It was also possible to validate the effect of entrenchment and convergence of interests in the relationship established between the insider ownership and performance.
\end{abstract}

Keywords: ownership concentration, insider ownership, operational performance, non-linear effects, SMEs, dynamic panel data

\section{Introduction}

In recent years numerous works have turned their attention to small and medium enterprises (SMEs) by virtue of their importance in terms of economic activity, job creation, innovation and ability to generate wealth in most economies (Behr, Norden, \& Noth, 2013). In market systems, survival issues and the complexity and dynamism of the business environment require an increasingly deep understanding of organizations in general and SMEs in particular, as well as key variables or factors to their performance.

As highlighted by agency theory, ownership concentration affects the relationship of the SMEs with other stakeholders, investment opportunities, company growth and consequently their performance. Dispersed ownership can lead to communication and coordination problems as a result of the diversity of owners and the separation of ownership and control (Chu, 2011, Wu, Xu, \& Phan, 2011). Meanwhile, supervision of the managers/directors by the owners intends to prevent unsuitable management practices or behaviours which are inconsistent with what must be the main objective of the principal (maximizing value for the owner), limiting management's immunity, known as "entrenchment" in the literature. Supervision, however, has costs and provides benefits to all of the owners in proportion to their holdings, so that few are interested in doing it. This phenomenon leads to "free-riding" problems and reduced performance. With a small number of owners the communication and coordination problems decrease as interests are more aligned, which can lead to greater oversight (Shleifer \& Vishny, 1986) or to less expropriation of minority shareholders (Shleifer \& Vishny, 1997).

Agency theory has contributed to the understanding of the problems underlying the conflict within organizations. From the conflicts of interest that can be generated between the various stakeholders, the literature has given greater attention to: i) conflicts between owners and managers/directors, ii) conflicts of interest between owners and the company's creditors (Jensen \& Mecklin, 1976), and iii) conflict between majority and minority owners, leading to problems of expropriation (Shleifer \& Vishny, 1986). 
In the scenario of apparent conflict, our main aim is to analyze the relationship between ownership structure (concentration and insider ownership) and operational performance using panel data models. In addition, we intend to study whether operational performance and ownership concentration, on the one hand, and insider ownership and operational performance, on the other, establish reciprocal relationships and to assess their interdependence using a system of simultaneous equations.

The main results show that ownership concentration has a U-shaped relationship with operational performance, in line with what Hu and Izumida (2008) obtained for Japanese family businesses. When compared with those obtained in similar studies in the Spanish business environment, they suggest an inverse relationship to that obtained by Miguel, Pindado and Torre (2004) for listed companies and confirm the relationship formulated but not validated by Arosa, Iturralde and Maseda (2010) for unlisted companies. The effects of entrenchment and convergence of interests are also confirmed in the relationship established between the insider ownership and operational profitability.

This paper is organized as follows. In addition to this introduction, it is comprised of five more sections. The second section is devoted to background research. The third section focuses on research design (hypotheses and proposed models). The fourth section presents the methodology, sample, data and variables. The results are presented and discussed in the fifth section. Finally, the sixth section presents the main conclusions of this study and suggests avenues for future work.

\section{Research Background}

The relationship between the ownership concentration, insider ownership and performance in companies has been an important and controversial issue in corporate governance. Agency theory states that the ownership structure is an important determinant of performance - causality of property for performance (Margaritis \& Psillaki, 2010, Arosa et al., 2010). However, studies such as those by Thomsen and Pedersen (2000) and Holderness (2003) argue that causality may be in the opposite direction under some circumstances - causality of performance for ownership structure. Although the impact of ownership structure on performance has been explored in the literature (e.g., Anderson and Reeb, 2003, Miguel et al., 2004), studies on the effect of performance feedback on ownership structure, are scarce and have been limited to the North American reality (e.g., Demsetz, 1983, Demsetz \& Lehn, 1985).

Research conducted on U.S. firms is based on a highly dispersed ownership, whereby it may have limited applicability (Cho, 1998, Demsetz \& Villalonga, 2001). In fact, continental countries are characterized by a concentrated ownership and strategically oriented towards stable relationships. These relationships ensure sustainable development rather than favouring performance or control rights over the company. In this context, the following questions are raised: $i$ ) if the ownership held by the main owners and by managers/directors plays an important role in determining corporate operational profitability, and ii) do the owners and the managers/directors change their level of ownership according to the company's operational profitability.

\subsection{Ownership Concentration and Performance}

Ownership concentration is one of the main mechanisms of corporate governance which influences agency costs (Jensen \& Meckling, 1976). Based on this premise, the effect of ownership concentration on performance has been widely documented in the literature with particular attention to companies in the United States and the United Kingdom. Since dispersion creates free riding problems and makes it difficult to supervise, a positive relationship is expected between ownership concentration and corporate performance. Consistent with this hypothesis supervision, Shleifer and Vishny (1986) refer to the important role played by large owners, and how the stock price rises as the percentage of shares held by them increases. Grossman and Hart (1986) argue that owners with a high stake in the company show greater willingness to play an active role in decisions as they can internalize the benefits of their monitoring effort. The method used by large owners to oversee the management/administration is a result of informal agreements drawn up amongst them (Shleifer \& Vishny, 1997). Nevertheless, ownership concentration can lead to conflicts between controlling and minority owners leading to worse performance, as advocated by expropriation hypothesis. The divergences induce a perverse widespread problem in that the controllers expropriate wealth from minority owners. Small investors fear being expropriated through inefficient investments yielding higher costs for the company (La Porta, Florencio, \& Shleifer, 1999). Sheifer and Vishny (1997) argue that in some countries, the agency costs resulting from the conflict of interest between controlling and minority owners are much more significant than those resulting from the separation of ownership and management (administration). Thus, high levels of ownership can generate costs, particularly when the majority owners do not redistribute wealth equitably with minority owners, because their interests do not always coincide. 
Several authors analyze the relationship between ownership concentration and performance to determine the existence of an optimal structure. For example, in a study conducted on 470 companies listed in the UK, Leech and Leahy (1991) document an inverse linear relationship between ownership concentration and performance. The same relationship was observed by Mudambi and Nicosia (1998) and Lehmann and Weigand (2000) for a sample of British and German companies, respectively.

Meanwhile, a linear and positive relationship between ownership concentration and performance is validated for a group of U.S. (e.g., Hill \& Snell, 1988, Agrawal \& Mandelker, 1990), Japanese (e.g., Kaplan \& Minton, 1994, Gedajlovic \& Shapiro, 1998) and German (e.g., Gorton \& Schmidt, 2000) companies. Gedajlovic and Shapiro (1998) reported that investors in the Japanese institutional context, are rather unprotected by the legal system and ownership is highly concentrated. Thus, minority owners, unlike what happens in other countries, are not expropriated since banks play an important role in corporate control. This leads to a convergence of interests between different owners and managers/directors.

Yet, when the dominant owners have enough power to control, they can maximize personal wealth at the expense of the company's value, leading to a conflict of interests between the majority and minority owner. In this sense, Miguel et al. (2004), while analyzing listed Spanish companies, conclude by a non-linear relationship between ownership concentration and the companies' market value. In particular, they conclude that companies' market value increases until ownership concentration reaches 87 percent as a result of the effect of supervision, but beyond this point minority owners may be expropriated. This leads to a decrease in the value of the company. Thus, an inverted U-shaped relationship is found. In order to explain the results obtained, the authors refers to a set of institutional features of the Spanish corporate governance system which differentiates it from previous studies, including: the level of ownership concentration, the effectiveness of boards of directors, the development of the capital market, the monitoring activity of the market over business activity, and the legal protection of investors. Other authors (e.g., Gedajlovic \& Shapiro, 1998, Anderson \& Reb, 2003) also provide support for a non-linear relationship between ownership concentration and performance, diverging, however, as to the value from which the effect of supervision replaces that of expropriation. This difference stems from different corporate governance systems, the legal protection of investors, the development of capital markets, the role of the market in corporate control, the industrial sector, among others (Shleifer \& Vishny, 1997, La Porta, López, Shleifer, \& Vishny, 1998).

In a more recent study of unlisted Spanish SMEs, Arosa et al. (2010) report that no relationship was identified between ownership concentration and performance. No evidence was found to corroborate the expropriation and supervision hypothesis for the companies analyzed. That is, the results obtained by Miguel et al. (2004), is based listed Spanish companies is uncorroborated for unlisted companies. In this case, the level of ownership concentration has no direct influence on the owners' behaviour. This may be related to the status of unlisted companies and their ownership concentration. Nevertheless, when dividing the sample depending on the nature of the ownership, the results suggest that the relationship between ownership concentration and performance differs depending on the generation which generates/manages the enterprise. In first-generation family businesses, a positive relationship between ownership concentration and performance is found for low levels of control rights, so that the supervision hypothesis prevails; a negative relationship is found for high levels of control rights, as expected by the expropriation hypothesis.

In the context of Japanese manufacturing enterprises, $\mathrm{Hu}$ and Izumida (2008) conducted a study where they analyze the causal relationship between ownership concentration and performance. The results suggest a U-shaped relationship between ownership concentration and performance, in line with the expropriation effect predominant in low levels of ownership and the supervision effect for intermediate levels of ownership, indicating that both dispersed ownership and high ownership concentration are associated with improved performance. On the other hand, they showed an insignificant effect of performance on ownership concentration, supported by the fact that capital markets have low liquidity, which prevents larger owners from changing their portfolios depending on performance. Considering the results, they conclude that ownership concentration is not determined by performance in illiquid markets, where it is difficult to transact and change ownership in response to changes in circumstances.

\subsection{Insider Ownership and Performance}

The relationship between insider ownership and performance can also be seen, within the context of agency theory, as one of the most relevant contributions to reduce agency problems between different stakeholders (Fama \& Jensen, 1983b, Demsetz \& Lehn, 1985, Jensen \& Meckling, 1976). Indeed, when the manager/director has no holding, he may not have sufficient incentives to develop creative activities (often required to maximize the company's value) such as, seeking innovative investment projects or incorporating new production technologies, leading to myopic 
policies (Jensen \& Meckling, 1976). The manager/director's stake in the capital can be a tool which will make him be more efficient or lead others to be so. Short-term incentives (salary) can be linked to long-term incentives (depending on results) translated by shares in the company, which serve as incentives or complementary compensatory systems to enhance the manager/director's preference for long-term results (Gaver \& Gaver, 1993). Jensen (1993) proposes a combination of incentives to increase shareholder value. Thus, the manager/director is rewarded by increasing their wealth and differences between managers/directors and owners are reduced (Mehran, 1995). Thus, managers/directors may receive stock or stock options.

In addition to ownership concentration, the company's performance can be influenced the decisions of the managers/directors and the way they use company resources to maximize personal wealth at the expense of business results (Oswald \& Jahera, 1991, Pegels, Song, \&Yong, 2000). According to Jensen and Meckling (1976), the natural tendency of managers/directors is to affect the company's resources for their own interests, which may lead to conflicts with other stakeholders. As insider ownership increases, interests converge and thus conflicts between managers/directors and owners tend to be resolved (Miguel et al., 2004). This convergence of interests hypothesis suggests that the company increases its value when the level of insider ownership rises. Nevertheless, high levels of insider ownership can generate costs as Fama and Jensen (1983a) point out. When the manager/director owns a substantial fraction of the company's capital, this gives him voting power and/or significant influence. This, in turn, may not comply with the objectives of maximizing value, without jeopardizing their employment and therefore their salary (Miguel et al., 2004).

Since one of the objectives pursued by governance mechanisms is to prevent managers/directors from taking inadequate measures or from performing in a manner that is inconsistent with maximizing value to the owner, a phenomenon of management immunity can sometimes develop. This is known in the literature as 'management entrenchment' (Costa, 1998). According to Berger, Ofek and Yermack (1997), 'management entrenchment' reflects the situation in which managers/directors are immune to the discipline imposed by a wide range of control mechanisms. The level of the managers/directors' 'entrenchment' may be enhanced by several factors, particularly the weight of ownership held and voting power in decision-making (Demsetz, 1983, Fama \& Jensen, 1983b, Bebchuk, Cohen, \& Ferrell, 2009).

Opposing effects of insider ownership on firm value, alignment of interests and management entrenchment, suggest a non-linear relationship between insider ownership and company performance. For low levels of insider ownership, there is a convergence of interests, agency costs decline and performance improves. In intermediate levels of insider ownership convergence costs (coincidence of ideas about how to run the business) outweigh gains and interest between managers and other owners may differ (Del Brio, Maia-Ramires, \& De Miguel, 2011). In order to maximize their own interest managers/directors can divert results and other company assets under their control, enjoy higher remuneration, place unqualified relatives in management positions, or become irreplaceable (La Porta, López, Shleifer, A., \& Vishny, 2000, Gomez-Mejia, Nunez-Nickel, \& Gutierrez, 2001).

Managers/directors can also choose to invest in projects that would be rejected when the rate of return required by the owners is considered, but which would meet their own expectations (Lisboa, 2007). For higher levels of insider ownership performance increases again, as the owner/manager/director of the company has additional incentives in valuing share price (Loderer \& Martin, 1997). A review of relevant literature (e.g., Mudambi \& Nicosia, 1998, Demsetz \& Villalonga, 2001, Gedajlovic \& Shapiro, 1998, Miguel et al., 2004) suggests that the relationship between insider ownership and performance has two inflection points; however, studies are not unanimous as to the percentage at which the inflection occurs and diverge in the models and variables used.

Most studies indicate that ownership concentration and insider ownership have a positive impact on performance. Nevertheless, Demsetz (1983) and Demsetz and Lehn (1985) question this causal relationship, indicating that ownership concentration should be thought of as endogenous, a consequence of the decisions of maximizing results for owners. Cho (1998), Himmelberg, Glenn Hubbard and Palia (1999) and Demsetz and Villalonga (2001) suggest that the variables of ownership are determined in equilibrium, endogenously. The positive or negative causal effect of performance on ownership is also reported by Thomsen and Pedersen (2000) and Holderrness, (2003). Expecting better performance, the owners who are controllers increase their holdings in order to have greater control and obtain a higher income, assuming good performance persists, thereby constituting an indicator of the positive effect of performance on ownership concentration (Hu \& Izumida, 2008). Conversely, if the value of the company is too high in relation to expectations generated and participation is subject to high risks, the owners are driven to sell part of their holdings. In this situation there is a negative effect of performance on ownership concentration (Hu \& Izumida, 2008). However, Zhou (2001) finds that ownership concentration has remained stable over the years, leading him to 
conclude that significant costs of adaptation and coordination make adjustments of ownership concentration more difficult.

Within the context of SMEs in general and family firms, in particular, ownership concentration often leads to the controlling shareholder/partner performing activities designed to extract private benefits (Shleifer \& Vishny, 1997, La Porta et al., 2000) by which operational profitability as a mechanism to induce greater participation by managers/directors in the company's capital and convergence of interests becomes less relevant. In this sense, some studies (e.g., Shleifer \& Vishny, 1997, Demsetz, 1983) suggest that controlling family shareholders/partners tend to defend their own interests, treating the company as a tool to provide employment to the family or as a way to obtain financing thereby limiting the top positions to family members.

\section{Research Design}

The focus of the related literature is usually on large firms with dispersed capital. The question, however, of assessing whether the results remain valid for small and family-oriented businesses has come up. To begin with, family owners, unlike the others, are more interested in the long term survival of the company. Agency problems seem less important in the context of these companies because the controlling owners already have enough incentives that give them power and information to control top managers/directors (Jensen \& Meckling, 1976). Nevertheless, high levels of ownership concentration can trigger other problems and other costs in the context of corporate governance. The free-rider and management entrenchment problems of the family members can override or even exceed the benefits of the agency agreement between owners and managers/directors (Schulze, Lubatkin, Dino, \& Buchholtz, 2001, Chua, Chrisman, \& Sharma, 2003). Conversely, the long term presence of family members in the company can increase the quality of results (Wang, 2006) and facilitate the company's technological knowledge, thus improving performance (Martikainen, Nikkinen, \& Vähämaa, 2009).

On the other hand, concern for reputation and the intention of preserving the family name are likely to involve a greater commitment on the part of owners, producing positive economic impacts. Family ties and reputation may limit the manager/director's acting for his own benefit when their family members manage the company (Denis, 1994). The family reputation may also foster long-term relationships, leading, for example, to a reduction of conflict of interests between owners and creditors and a lower cost of financing (Anderson \& Reeb, 2003).

Problems arising from the separation of ownership and control are reduced in first generation family businesses because the same person is responsible for the management/administration, for investment decisions and supervision (Schulze et al., 2001). Agency costs can be reduced by completely eliminating separation of ownership and control. In these cases, the interests of the principal and the agent are aligned, so that the management will not expropriate the wealth of the owners (Miller \& Le Breton-Miller, 2006). When the company incorporates later generations, priorities are altered; ownership is shared by a growing number of members and conflicts can arise if interests are not aligned, and the relationships between the various participants are influenced by economic and personal preferences (Chrisman, Chua, \& Sharma, 2005, Sharmaa, Hoyb, Astrachanc, \& Koiranen, 2007). Over time the economic incentive to maximize personal utility can induce the controlling owner to confuse family objectives (interests) with the business objectives (Schulze, Lubatkin, \& Dino, 2002). According to Anderson and Reeb (2003), the founding owner grants the company valuable capabilities, unlike his successors who intervene less towards productivity and efficiency. This argument is consistent with empirical evidence which testifies that firms managed by their founder perform better than others (e.g., Villalonga \& Amit, 2006, Baraontini \& Caprio, 2006, Pindado, Requejo, \& de la Torre, 2011).

Based on the theoretical references developed in the previous section we have formulated the following hypotheses:

Hypothesis 1: There is a non-linear relationship between ownership concentration and the company's operational profitability, which first increases and then decreases.

To test this hypothesis, the following model was estimated:

$$
E R A_{i t}=\beta_{10}+\beta_{11} E R A_{i(t-1)}+\beta_{12} C_{i t}+\beta_{14} C_{i t}^{2}+\varepsilon_{i t}
$$

where ERA and $\mathrm{C}$ represent operational profitability and ownership concentration, respectively.

As shown in the model, operational profitability in time $t$ is a function of operational profitability at time $\mathrm{t}-1$. The persistence of results - the company that operates well can continue to do so (Goddard \& Wilson, 1999) - leads the operational profitability of the previous year to be positively associated with that of the current year. The literature review states that the effect of supervision and expropriation may occur simultaneously, suggesting a non-linear effect. The main advantage of the linear quadratic regression model is the presence of an inflection point, which 
takes in a change in the slope, the earliest symptom of the prevalence of the supervision and expropriation hypotheses.

Another aim is to investigate empirically if age is a potentiating factor of the effect of ownership concentration on operational profitability, reflected in the fact that it reduces or increases the magnitude and direction of this effect. The importance of considering this effect has already been suggested by Morck, Nakamura, and Shivdasani (2000). The classification of companies based on age is associated with two recent problems in research: $i$ ) the decision of succession within the family business and ii) the generation of the family that exercises domination. Bennedsen, Nielsen, Pérez-González and Wolfenzon (2007) report a decline in corporate performance with the succession of family managers/directors. They also reveal that companies where the founder is in charge of management/administration show better performance in relation to others (Villalonga \& Amit, 2006).

Therefore, we formulate the second hypothesis.

Hypothesis 2: The relationship between ownership concentration and operational profitability is stronger in young companies than in 'mature' ones.

To test this hypothesis in Model 1 a dummy variable $Y M$ is introduced. It takes the value "one" if the company is young and zero in all other cases and a model is formulated in which the existence iterative effects between ownership concentration and this dummy is admitted. For purposes of classification as "young" and "mature", we felt that a company is "young" when its age is below the sample mean in line with (Pindado et al., 2011).

$$
E R A_{i t}=\beta_{20}+\beta_{21} E R A_{i(t-1)}+\left(\beta_{22}+\beta_{23} Y M_{i t}\right) C_{i t}+\left(\beta_{24}+\beta_{25} Y M_{i t}\right) C_{i t}^{2}+\varepsilon_{i t}
$$

where ERA and $\mathrm{C}$ represent operational profitability and ownership concentration, respectively. $Y M_{i t}$ is a dummy which equals 1 if the age of the company is lower than the mean and zero otherwise.

Regarding insider ownership the following hypothesis is formulated:

Hypothesis 3: A company's operational profitability increases with insider ownership for low and high levels (as a result of the effect of convergence of interest) and decreases for intermediate levels (as a result of the effect the managers' entrenchment).

In order to test this hypothesis, a model that postulates a cubic relationship between operational profitability and insider ownership was formulated.

$$
E R A_{i t}=\beta_{30}+\beta_{31} E R A_{i(t-1)}+\beta_{32} I O_{i t}+\beta_{33} I O_{i t}^{2}+\beta_{34} I O_{i t}^{3}+\varepsilon_{i t}
$$

where ERA is the operational profitability and $I O, I O^{2}$ and $I O^{3}$, is the percentage of equity held by managers/directors, its square and its cube, respectively.

A fourth hypothesis addresses the effect of operational profitability on ownership concentration:

Hypothesis 4: The company's operational profitability has a positive impact on ownership concentration which is an incentive for the owner to exert greater control.

To test this hypothesis, the model is as follows:

$$
C_{i t}=\beta_{40}+\beta_{41} C_{i(t-1)}+\beta_{42} E R A_{i t}+\beta_{43} E R A_{i(t-1)}+\varepsilon_{i t}
$$

where $\mathrm{C}$ and ERA represent ownership concentration and operational profitability, respectively.

In opposition to the causality advocated in Hypothesis 1, performance has been recognized to have an inverted relationship on ownership concentration in the literature (e.g., Thomsen \& Pedersen, 2000, Holderness, 2003). Companies with good operational profitability are a strong incentive for concentrating ownership, resulting in greater control and/or a higher volume of rights on the assumption that it will persist, indicating a positive effect.

Regarding what conditions insider ownership, corporate performance is a strong incentive for greater involvement of the manager/director in the company's equity.

Hypothesis 5: The company's operational profitability has a positive impact on insider ownership constituting an incentive to practice efficient management/administration and to reduce conflicts between owners and managers/directors.

To test this hypothesis, the following model was estimated:

$$
I O_{i t}=\beta_{50}+\beta_{51} I O_{i(t-1)}+\beta_{52} E R A_{i t}+\beta_{53} E R A_{i(t-1)}+\varepsilon_{i t}
$$

where IO and ERA represent insider ownership and operational profitability, respectively. 


\section{Methodology, Sample, Data and Variables}

\subsection{Methodology}

Panel data is used to estimate the models formulated. This choice is motivated by the relevance of two important issues in the study of the impact of ownership concentration and insider ownership on operational profitability: i) unobserved heterogeneity (corporate characteristics that influence operational profitability are difficult to measure or obtain) and ii) problems of individual endogeneity. Unobserved heterogeneity was controlled the through the individual effect $\eta_{\mathrm{i},-}$ corporate specificities giving rise to specific behaviour, and the effect of time, $d_{t}$. What is considered the error term in the model, $v_{i t}$ is divided into three distinct components: the first is the individual effect $\eta_{\mathrm{i}}$, the second $d_{t}$ the time effect and the third $\mu_{\text {,it }}$ random disturbance. Moreover, the potential endogeneity of ownership concentration and insider ownership may condition the relationship with operational profitability, so that instrumental variables are used and the Generalized Method of Moments (GMM).

Consider the following generic specification for a data panel model referring to the sectional unit $i$ at moment $t$

$$
Y_{i t}=\beta_{0 i t}+\sum_{i=1}^{k} \beta_{k i t} X_{i t}+v_{i t} \quad \mathrm{i}=1, \ldots \mathrm{N} \text { and } \mathrm{t}=1, \ldots \mathrm{T}
$$

where:

$$
\begin{aligned}
& Y_{i t}-\text { observed value of the dependent variable for individual } i \text { at moment } t \\
& \beta_{0 i t}-\text { independent regression term for individual } i \text { at moment } t \\
& \beta_{k i t}-\text { regression coefficient of the } \mathrm{K} \text { variable for individual } i \text { at moment } t \\
& X_{i t}-\text { observed value of explanatory variable } \mathrm{K} \text { for individual } i \text { at moment } t \\
& v_{i t}-\text { residual term (the regression error) for individual } i \text { at moment } t \text {, equal to } \eta_{\mathrm{i}}+\mathrm{d}_{\mathrm{t}}+\mu_{\mathrm{it}} \\
& \mathrm{N}-\text { number of sectional units (individuals) } \\
& \mathrm{T}-\text { number of time periods }
\end{aligned}
$$

Decomposition of the error term allows the panel data methodology to consider that the effect is not observed, $\eta_{i}$ is correlated with the explanatory variables. Since $\eta_{\mathrm{i}}$ is constant over time, data over two consecutive periods can be distinguished, giving rise to a new equation, known as the first-difference equation, where $\eta_{\mathrm{i}}$ is not found (it was removed by differentiation). The inclusion of lagged values for the explanatory variables gives rise to endogeneity, reflected in the fact that it is correlated with the error term, so that the estimators obtained by the Ordinary Least Squares (OLS) method are biased and inconsistent. Thus, the Generalized Method of Moments (GMM) is used in estimating our models, which allows us to control endogeneity using instruments - variables that satisfy two conditions: i) not being correlated with $v_{i t}$, i.e. $\operatorname{Cov}\left(Z_{i t}, v_{i t}\right)=0$ and ii) they are correlated with $X_{i t}$, i.e. Cov $\left(Z_{i t}, X_{i t}\right) \neq 0$.

Under the GMM, the best known test is the over-identification test, or $J$ test proposed by Hansen, which allows the quality of the instruments to be measured. The clearest way to test the specification of a model is to check if the values of all the conditions of the sample moments are close to zero or not, since the GMM only requires their $k$ linear combinations to be. The $J$ statistic has an asymptotic distribution of chi-square with $s-k$ degrees of freedom.

In models with time series the presence of a positive correlation between adjacent errors is often found, symbolically expressed by $\mathrm{E}\left(\varepsilon_{\mathrm{i}}, \varepsilon_{\mathrm{j}}\right) \neq 0, \forall \mathrm{i} \neq \mathrm{j}$. One of the situations in which the regressores are not strictly exogenous occurs when the model contains a lagging dependent variable: $Y_{i t}$ and $\mu_{i t}$ are correlated. To test the autocorrelation of the error term we use the Arellano and Bond (1991) statistic for autocorrelation under the null hypothesis of zero serial correlation. Negative serial correlation in the first order differences is expected, resulting from the relationship between $\Delta \varepsilon_{\mathrm{i}}$, t and $\Delta \varepsilon_{\mathrm{i}}$, t-1 through the $\varepsilon_{\mathrm{i}, \mathrm{t}-1}$ term, so that a serial correlation of order $\mathrm{r}$ with $\mathrm{r}=2, \ldots, \mathrm{T}$ should be sought.

The need to estimate the mutual relations between operational profitability, ownership concentration and insider ownership requires a simultaneous equations model to be adopted, with a number of equations equal to the endogenous variables. The existing statistical programs (e.g., STATA) do not include routines for estimating systems of simultaneous equations with panel data, considering them cross-section data, leading to inefficient estimates.

\subsection{Sample, Data and Variables}

The selecting SMEs as object of study arises from the fact that they possess a set of particular characteristics. Firstly, because in most cases they are unlisted companies, they face greater information problems compared to larger enterprises. The tenuous separation between ownership and management in SMEs, greatly increases information asymmetry between insiders and outsiders. Secondly, SMEs are limited in obtaining external funds from financial 
institutions to the extent that the market is accessible only to large companies both, by virtue of transaction costs, and by the information asymmetries that small firms are exposed to. Thirdly, these firms are of particular importance in the fabric of most entrepreneurial economies, and Portugal is no exception. According to a study by the IAPMEI Planning and Studies Directorate in February 2008, SMEs represent $99.6 \%$ of the Portuguese business units, creating $75.2 \%$ of private employment and performing over half of all turnover (56.4\%) generating about 2.1 million jobs and over $€ 170.3$ billion turnover.

The study is carried out on a set of non-financial firms over the period from 2003 to 2008. The period time considered, 2003-08, allows two of the methodology's limitations to be controlled for: unobserved heterogeneity and endogeneity. Thus, information for a period of at least four consecutive years by the company becomes necessary to be able to test the absence of second order serial correlation as mentioned by Arellano and Bond (1991), one of the assumptions of the estimation method adopted (GMM).

The main source of information was the SABI (Iberian Balances Analysis System), which contains accounting and financial information on Portuguese and Spanish firms. Among the firms listed in the SABI database: $i$ ) those without accounting information during the review period were eliminated, $i$ ) only those that met the conditions set by the Bank of Portugal in their analyses (total assets, equity, turnover and positive GVA) were included, iii) those which were not economically viable, reflected by a positive operational profitability, were excluded $i v$ ) only those which met the conditions for SMEs to under Decree-Law No. 372/2007 were taken into account, $v$ ) companies in the financial sector were removed and, finally, vi) only those companies for which information regarding equity distribution was available were retained. Given these criteria, a final sample of 4,163 firms was reached.

Table 1 presents some characteristics of the companies in the sample: distribution of companies by number of employees, job creation and turnover by scaled number of employees. Analysis of this table indicates that $89 \%$ of the companies have fewer than 50 employees. Nevertheless, it is those with 10 or more workers that absorb $90 \%$ of the labour and have $83 \%$ of turnover. It is worth noting that a significant number of companies (43\%) have fewer than 10 employees, but their contribution to generate business and create value is of little importance (17\%). Regarding companies with 50 or more people, though their number is reduced (11\%), they absorb $45 \%$ of the workforce and account for $36 \%$ turnover.

Table 1. Main characteristics of the sample by class according to number of employees, average values 2003-2008

\begin{tabular}{lrrrrrrr}
\hline Variables & \multicolumn{1}{c}{ Total } & \multicolumn{2}{c}{ Less than 10} & \multicolumn{2}{c}{10 to 49} & \multicolumn{2}{c}{50 to 249} \\
\cline { 2 - 8 } & Value & Value & $\%$ & Value & $\%$ & Value & $\%$ \\
\hline Companies (No.) & 4.163 & 1.777 & 43 & 1.928 & 46 & 458 & 11 \\
Employees (No.) & 94.539 & 9.504 & 10 & 42.422 & 45 & 42.612 & 45 \\
Turnover (10 ${ }^{3}$ Eur) & 12.313 .887 & 2.037 .058 & 17 & 5.796 .657 & 47 & 4.480 .172 & 36 \\
\hline
\end{tabular}

To measure each attribute, we take into account the indicators used by other authors from the accounting information given the absence of market values for the population under study (SMEs). The use of operational profitability indicators as an expression of corporate performance is supported in many empirical studies, highlighting economic profitability (ERA), expressed in the asset's capacity to generate results (e.g., Thomsen \& Pedersen, 2000, Aras, Aybars, \& Kutlu, 2010, Greenaway, Guariglia, \& Yu, 2012, Masulis, Wang, \& Xie, 2012, Castelli, Dwyer, \& Hasan, 2012, Wang \& Sarkis, 2013).

As it is difficult to reach a consensus on the best way to assess ownership structure and the literature suggests different ways to quantify it, we propose ownership concentration and insider ownership as characteristics that identify it best, since these are simple and intuitive variables, less prone to measurement error and not subject to the problems of weighting. Ownership concentration $(C)$ indicates the percentage of equity held by the two largest owners and insider ownership (IO) the part of the equity held by the managing bodies/directors (Anderson \& Reeb, 2003, Villalonga \& Amit, 2006). The variables used in the models and sample segmentation criteria are defined in Table 2.

We consider a company young when its age is below the mean of the companies in the sample, yielding a dummy variable $(Y M)$ which is equal to one if the company is young, and zero otherwise (Pindado et al., 2011). As for the nature of the ownership, it is a family company if the main partner/shareholder is an individual or family with at least $50 \%$ of the equity (Anderson \& Reeb, 2003, Wang, 2006). The business dimension is evaluated by a set of variables to classify firms according to a multicriteria vector that combines the number of employees, turnover and total assets. Decree-Law No. 372/2007 is adopted as a basis, gathering together micro, small and average enterprises. 
Table 2. Variables used in the models and sample segmenting criteria

\begin{tabular}{|c|c|}
\hline \multicolumn{2}{|r|}{ Panel A: Variables used in the models } \\
\hline Variable & Definition \\
\hline $\begin{array}{l}\text { Economic return on } \\
\text { assets }\end{array}$ & $\begin{array}{l}E R A_{i t}=\mathrm{OP}_{\mathrm{it}} / \mathrm{A}_{\mathrm{it}} \text {, where } \mathrm{OP}_{\mathrm{it}} \text { is the operational profitability and } \mathrm{A}_{\mathrm{it}} \text { is the total } \\
\text { assets. It measures the capacity of the company's assets to generate results. }\end{array}$ \\
\hline $\begin{array}{l}\text { Ownership } \\
\text { concentration }\end{array}$ & $\begin{array}{l}C_{i t} \text { expresses the holdings of the two largest partners/shareholders of the } \\
\text { company's equity. }\end{array}$ \\
\hline Insider ownership & $\begin{array}{l}I O_{i t} \text { is the equity held by whoever performs management duties. It gives the } \\
\text { percentage of the ownership held by the managers/directors. }\end{array}$ \\
\hline Dummy & $Y M_{i t}$ is a dummy which is equal to 1 if the age of the company is lower than the \\
\hline Young/Mature & mean and zero otherwise. \\
\hline Lagged variable & $X_{(t-l)}$ denotes that the variable $\mathrm{X}$ is lagging by one period. \\
\hline Time dummy & $D_{(t)}$ is the dummy of period $t$. \\
\hline \multicolumn{2}{|r|}{ Panel B: Sample segmenting criteria } \\
\hline Criterion & Description \\
\hline \multicolumn{2}{|l|}{ Age } \\
\hline Young & Age of the company is lower than the sample mean \\
\hline Mature & Age of the company is higher than the sample mean \\
\hline \multicolumn{2}{|l|}{ Nature of Ownership } \\
\hline Family & Percentage of family in equity greater than $50 \%$ \\
\hline Non-Family & Percentage of family in equity less than $50 \%$ \\
\hline
\end{tabular}

Micro $\quad$ Classification as a micro enterprise as defined by Decree-Law No. 372/2007

Small Classification as a small enterprise as defined by Decree-Law No. 372/2007

Medium Classification as an average enterprise as defined by Decree-Law No.

$372 / 2007$

Note: Decree-Law No. 372/2007 defines micro, small and medium businesses. The category of micro, small and medium enterprises is made up of enterprises which employ fewer than 250 persons and whose annual turnover does not exceed $€ 50$ million or whose total annual balance sheet does not exceed $€ 43$ million. A small business is defined as an enterprise which employs fewer than 50 persons and whose annual turnover or total annual balance sheet does not exceed $€ 10$ million. A micro enterprise is defined by employing less than 10 persons and whose annual turnover does not exceed $€ 2$ million.

\section{Results}

In this section we present the results of the proposed models in order to test the hypotheses. The estimates for the parameters in each model were obtained through the Generalized Method of Moments (GMM). This was followed up with tests to assess their quality. In all of the models, the Arellano and Bond (1991) test reveals no correlation between the errors, with Hansen's test validating the instruments used, so that the methodology used is found to be suitable.

\subsection{Ownership Concentration and Firm Operational Performance}

Estimation results of the model first formulated using the GMM, are found in Table 3 column I, when considering the totality of the sample companies. The values obtained suggest that ownership concentration has a non-linear impact on corporate operational profitability, expressed in the significance of regression coefficients. In particular, the coefficient of the ownership concentration variable is negative $\left(B_{1}<0\right)$ and its square is positive $\left(B_{2>}\right)$, which represents a quadratic U-shaped relationship. This means that the expropriation hypothesis prevails for low levels of control rights and the supervision hypothesis for high levels. The results have revealed themselves significant, unlike what happened in Arosa et al. (2010) and Westhead and Howorth (2006), and establish a contrary relationship to that obtained by Miguel et al. (2004) for Spanish listed companies. Nevertheless, they are in consonance with the findings of $\mathrm{Hu}$ and Izumida (2008) for small family businesses in Japan. The negative effect of ownership concentration on operational profitability for low levels of concentration suggests that two potential costs prevail. On the one hand, there is an incentive for the owner to take actions that increase their personal utility, reducing corporate performance, which may be associated with less efficient investment decisions (Cronqvist \& Nilsson, 2003). On the other hand, Gomez-Mejia et al. (2001) suggest that as the concentration of family ownership increases there is an influence of family control over managers/directors, which can lead to greater entrenchment. The inversion of the concavity of the quadratic relationship, over that obtained in other studies focusing on large enterprises, may be related to the fact that the latter possess external control systems, professional management and more dispersed ownership where the holders of the equity purchase and sell shares in high liquidity securities markets. In listed 
companies, ownership loses its relevance as a mechanism of supervision, as this is ensured by external (market) forces. Conversely, in small businesses internal control systems and more concentrated ownership prevail and less efficiency of securities markets is felt. The ownership structure thus plays an important role in disciplining managers/directors and significant determines performance for lack of effective external control.

A quadratic relationship proposed in model 1 shows only one inflection point that can be determined by deriving the function in relation to ownership concentration. Calculating the first derivative and making it equal to zero, we obtain the variable value where the function reaches an extreme. Since the coefficient of the term of higher degree is positive, we can say that the function has a minimum at $C_{1}=-\left(B_{I} / 2 B_{2}\right)$, which for this sample is $68.69 \%$. The fact that the coefficient $B_{2}$ presents a very low value indicates that the parabola has a "very open" U-shape. These values allow us to conclude that there is a quadratic relationship between ownership concentration and operational profitability as advocated by Hypothesis 1 . Nevertheless, concavity is inverted.

Columns II, III and IV of Table 3 show the results of the estimation of model 1, for the sample segmented by size according to the criteria defined in Table 2 (Panel B). The results obtained when considering all firms in the sample remain valid for the subsamples: micro, small and medium enterprises. Nevertheless, the break point, where the expropriation effect gives rise to the supervision effect, changes. It appears that micro and small enterprises have a value of $80.47 \%$ and $71.51 \%$, respectively, placing them above the value obtained for the total sample firms. For medium-sized companies the inflection point is found at lower levels, 57.04\%. The results indicate that as the company increases in size, the supervision effect prevails from lower levels of ownership concentration. Thus, the estimates suggest that larger firms are subject to mechanisms of higher scrutiny.

In columns $\mathrm{V}$ and $\mathrm{VI}$ of Table 3, we consider the segmenting criterion firm age, according to the criterion found in Table 2 (Panel B). The model parameters remain significant as the conclusions remain valid for all firms in the sample. Nevertheless, the supervision effect of the "mature" companies replaces the expropriation effect at lower levels of ownership concentration than obtained for the total sample, with the value of $67.18 \%$. "Young" firms need to achieve a concentration of $74.19 \%$ for the supervision effect to prevail. Adopting the nature of ownership (family/non-family) as a segmenting criterion, the significance of ownership concentration on operational profitability is only validated for family businesses (see columns VII and VIII of Table 3).

Finally, columns IX, X, XI and XII of Table 3 show the estimation of model 1 intersecting two segmenting criteria: nature of ownership and age. The coefficients obtained lead us to assert that the relationship between ownership concentration and operational profitability are only significant in young family firms. These results suggest that their owners are more motivated to expropriate businesses. It is important to highlight the fact that the break point presents the highest value within the estimations made, reaching $80.55 \%$. We can say that in family businesses ownership concentration becomes significant with regards to operational profitability, largely attributable young family firms.

Table 3. Results of estimation of impact of ownership concentration on operational profitability

\begin{tabular}{|c|c|c|c|c|c|c|c|c|c|c|c|c|}
\hline & \multicolumn{3}{|c|}{ Total sample } & \multicolumn{9}{|c|}{ Size } \\
\hline & & & & \multicolumn{3}{|c|}{ Micro } & \multicolumn{3}{|c|}{ Small } & \multicolumn{3}{|c|}{ Medium } \\
\hline & \multicolumn{3}{|c|}{ I } & \multicolumn{3}{|c|}{ II } & \multicolumn{3}{|c|}{ III } & \multicolumn{3}{|c|}{ IV } \\
\hline & Coef. & Std. Err. & $\mathrm{P}>|\mathrm{t}|$ & Coef. & Std. Err. & $\mathrm{P}>|\mathrm{t}|$ & Coef. & Std. Err. & $\mathrm{P}>|\mathrm{t}|$ & Coef. & Std. Err. & $\mathrm{P}>|\mathrm{t}|$ \\
\hline \multicolumn{13}{|l|}{$\mathrm{ERA}_{\mathrm{it}}$} \\
\hline ERA $_{i(t-1)}$ & 0,36560 & 0,032750 & $* * *$ & 0,34761 & 0,040515 & $* * *$ & 0,29735 & 0,104723 & $* * *$ & 0,28182 & 0,14601 & $*$ \\
\hline $\mathrm{C}_{\mathrm{it}}$ & $-0,00043$ & 0,000148 & $* * *$ & $-0,00075$ & 0,000407 & * & $-0,00068$ & 0,000342 & $* *$ & $-0,00089$ & 0,000402 & $* *$ \\
\hline $\mathrm{C}^{2}{ }_{\mathrm{it}}$ & $3,16 \mathrm{E}-06$ & 0,000001 & $* * *$ & 4,64E-06 & 0,000003 & $*$ & 4,77E-06 & 0,000002 & $* *$ & $7,76 \mathrm{E}-06$ & 0,000003 & $* *$ \\
\hline $\mathrm{D}_{(\mathrm{t}-4)}$ & 0,06120 & 0,005928 & $* * *$ & 0,07967 & 0,015513 & $* * *$ & 0,07301 & 0,014280 & $* * *$ & 0,07669 & 0,017419 & $* * *$ \\
\hline $\mathrm{D}_{(\mathrm{t}-3)}$ & 0,05856 & 0,005950 & $* * *$ & 0,07617 & 0,015652 & $* * *$ & 0,07375 & 0,014602 & $* * *$ & 0,07107 & 0,016097 & $* * *$ \\
\hline $\mathrm{D}_{(\mathrm{t}-2)}$ & 0,05783 & 0,005972 & $* * *$ & 0,07624 & 0,015553 & $* * *$ & 0,07076 & 0,014741 & $* * *$ & 0,06774 & 0,015419 & $* * *$ \\
\hline $\mathrm{D}_{(\mathrm{t}-1)}$ & 0,06127 & 0,006014 & $* * *$ & 0,07814 & 0,015589 & $* * *$ & 0,07512 & 0,014721 & $* * *$ & 0,06884 & 0,015044 & $* * *$ \\
\hline $\mathrm{D}_{(\mathrm{t})}$ & 0,04235 & 0,006144 & $* * *$ & 0,05178 & 0,015622 & $* * *$ & 0,06385 & 0,015066 & $* * *$ & 0,06117 & 0,015197 & $* * *$ \\
\hline $\operatorname{AR}(2)$ & 2,540 & & 0,011 & 1,440 & & 0,149 & 1,020 & & 0,309 & $-0,640$ & & 0,521 \\
\hline $\operatorname{AR}(3)$ & 1,040 & & 0,297 & 1,130 & & 0,258 & 0,260 & & 0,797 & $-0,250$ & & 0,800 \\
\hline Hansen & 17,850 & & 0,022 & 15,050 & & 0,239 & 18,140 & & 0,020 & 6,210 & & 0,624 \\
\hline
\end{tabular}


Table 3. Results of estimation of impact of ownership concentration on operational profitability (cont.)

\begin{tabular}{|c|c|c|c|c|c|c|c|c|c|c|c|c|}
\hline & \multicolumn{6}{|c|}{ Age } & \multicolumn{6}{|c|}{ Nature of ownership } \\
\hline & \multicolumn{3}{|c|}{ Young } & \multicolumn{3}{|c|}{ Mature } & \multicolumn{3}{|c|}{ Family } & \multicolumn{3}{|c|}{ Non-Family } \\
\hline & \multicolumn{3}{|c|}{$\mathrm{V}$} & \multicolumn{3}{|c|}{ VI } & \multicolumn{3}{|c|}{ VII } & \multicolumn{3}{|c|}{ VIII } \\
\hline & Coef. & Std. Err. & $\mathrm{P}>|\mathrm{t}|$ & Coef. & Std. Err. & $\mathrm{P}>|\mathrm{t}|$ & Coef. & Std. Err. & $\mathrm{P}>|\mathrm{t}|$ & Coef. & Std. Err. & $\mathrm{P}>|\mathrm{t}|$ \\
\hline \multicolumn{13}{|l|}{$\mathrm{ERA}_{\mathrm{it}}$} \\
\hline $\mathrm{ERA}_{\mathrm{i}(\mathrm{t}-1)}$ & 0,33770 & 0,040234 & $* * *$ & 0,44287 & 0,052614 & $* * *$ & 0,37433 & 0,032751 & $* * *$ & 0,39225 & 0,091375 & $* * *$ \\
\hline $\mathrm{C}_{\mathrm{it}}$ & $-0,00048$ & 0,000275 & * & $-0,00039$ & 0,00015 & $* *$ & $-0,00029$ & 0,000175 & $*$ & $-0,00014$ & 0,000316 & \\
\hline $\mathrm{C}_{\text {it }}^{2}$ & $3,21 \mathrm{E}-06$ & 0,000002 & $*$ & $2,87 \mathrm{E}-06$ & 0,000001 & $* * *$ & $2,04 \mathrm{E}-06$ & 0,000001 & $*$ & $1,34 \mathrm{E}-06$ & 0,000003 & \\
\hline $\mathrm{D}_{(\mathrm{t}-4)}$ & 0,06727 & 0,010556 & $* * *$ & 0,05288 & 0,006445 & $* * *$ & 0,05556 & 0,006775 & $* * *$ & 0,06095 & 0,010897 & $* * *$ \\
\hline $\mathrm{D}_{(\mathrm{t}-3)}$ & 0,06513 & 0,010564 & $* * *$ & 0,04958 & 0,006625 & $* * *$ & 0,05338 & 0,006831 & $* * *$ & 0,05395 & 0,010955 & $* * *$ \\
\hline $\mathrm{D}_{(\mathrm{t}-2)}$ & 0,06580 & 0,01063 & $* * *$ & 0,04716 & 0,006618 & $* * *$ & 0,05249 & 0,006811 & $* * *$ & 0,05477 & 0,011329 & $* * *$ \\
\hline $\mathrm{D}_{(\mathrm{t}-1)}$ & 0,06989 & 0,010672 & $* * *$ & 0,05059 & 0,006649 & $* * *$ & 0,05563 & 0,006815 & $* * *$ & 0,06135 & 0,011823 & $* * *$ \\
\hline $\mathrm{D}_{(\mathrm{t})}$ & 0,05188 & 0,01089 & $* * *$ & 0,03186 & 0,006782 & $* * *$ & 0,03695 & 0,006917 & $* * *$ & 0,03996 & 0,012432 & $* * *$ \\
\hline $\mathrm{AR}(2)$ & 1,960 & & 0,050 & 0,990 & & 0,321 & 2,500 & & 0,013 & 0,950 & & 0,344 \\
\hline $\mathrm{AR}(3)$ & 0,950 & & 0,344 & 0,550 & & 0,579 & 1,320 & & 0,186 & $-0,100$ & & 0,917 \\
\hline Hansen & 11,540 & & 0,173 & 12,880 & & 0,116 & 14,840 & & 0,062 & 19,240 & & 0,014 \\
\hline
\end{tabular}

Table 3. Results of estimation of impact of ownership concentration on operational profitability (cont.)

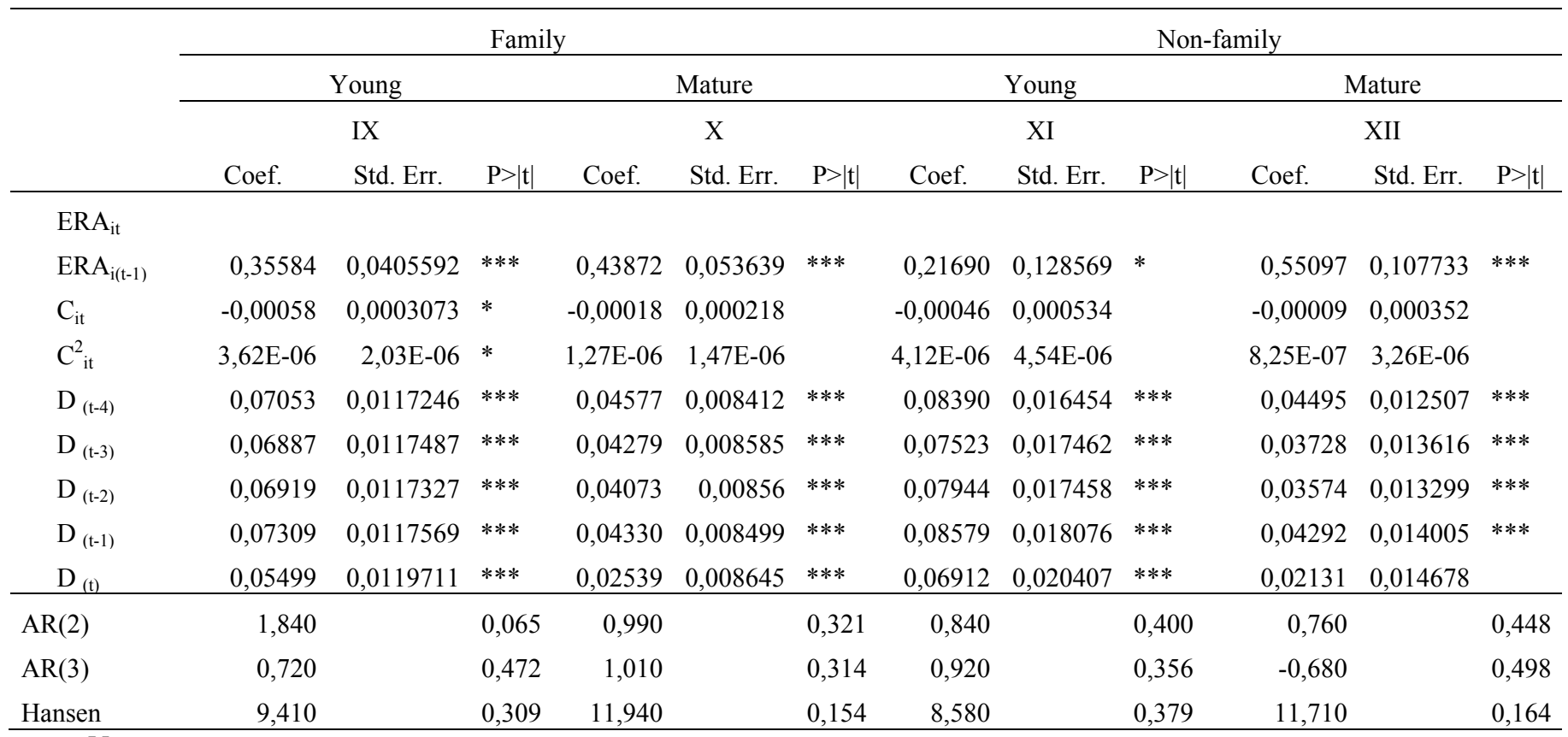

\section{Notes:}

The information required to interpret the tables is as follows: i) estimating the data was performed using GMM estimators as dynamic panel data using xtabond2 developed by David Roodman (2006); ii) ***, ** and * indicate the significance level at $1 \%, 5 \%$ and $10 \%$ respectively, iii) to eliminate the individual effects, the model was estimated after considering the first differences for the variables, iv) Arellano and Bond (AR) is a test of the autocorrelation of errors developed in order to verify if there are lags that are not valid instruments, and v) Hansen is a test of the over-identifying restrictions, asymptotically distributed as $\chi^{2}$ under the null hypothesis of no correlation between the instruments and the error term.

$\mathrm{ERA}_{\mathrm{it}}=$ Economic return on assets of the firm $i$ at the period $t, \mathrm{C}=$ Ownership concentration, and $\mathrm{D}_{(\mathrm{t})}=\mathrm{Dummy}_{\mathrm{m}}$ period $t$. 


\subsection{The Moderating Effect of Age}

The results of the second model formulated are presented in Table 4, showing the moderating effect of age on the relationship established in the previous model. Analysis of the regression coefficients associated with $C_{i t} \times Y M_{i}$ and $C^{2}{ }_{i t} \times Y M_{i}$ allows us to conclude that there is an interaction between ownership concentration and age (i.e., the relationship between ownership concentration and operational profitability is moderated by age). The values suggest that age influences and enhances the relationship established in the previous model, in line with previous empirical results (e.g., Anderson \& Reeb, 2003 and Baronitini \& Caprio, 2006). The entire model's estimated coefficients are significant, with the previous references remaining valid, allowing Hypothesis 2 to be validated.

Table 4. Results of the estimation of the impact of ownership concentration on operational profitability, with the moderating effect of age

\begin{tabular}{lrrr}
\hline & \multicolumn{3}{c}{ Total sample } \\
& \multicolumn{1}{c}{ Coef. } & Std. Err. & $\mathrm{P}>|\mathrm{t}|$ \\
\hline ERA $_{\mathrm{it}}$ & & & \\
ERA $_{\mathrm{i}(\mathrm{t}-\mathrm{l})}$ & 0,36906 & 0,032617 & $* * *$ \\
$\mathrm{C}_{\mathrm{it}}$ & $-0,00051$ & 0,000154 & $* * *$ \\
$\mathrm{C}^{2}{ }_{\mathrm{it}}$ & $3,73 \mathrm{E}-06$ & $1,12 \mathrm{E}-06$ & $* * *$ \\
$\mathrm{C}_{\mathrm{it}} \times \mathrm{YM}_{\mathrm{i}}$ & $2,15 \mathrm{E}-04$ & 0,000099 & $* *$ \\
$\mathrm{C}^{2}{ }_{\mathrm{it}} \times \mathrm{YM}_{\mathrm{i}}$ & $-1,75 \mathrm{E}-06$ & $1,02 \mathrm{E}-06$ & $*$ \\
$\mathrm{D}_{(\mathrm{t}-4)}$ & 0,05988 & 0,005842 & $* * *$ \\
$\mathrm{D}_{(\mathrm{t}-3)}$ & 0,05737 & 0,005863 & $* * *$ \\
$\mathrm{D}_{(\mathrm{t}-2)}$ & 0,05686 & 0,005886 & $* * *$ \\
$\mathrm{D}_{(\mathrm{t}-1)}$ & 0,06056 & 0,005934 & $* * *$ \\
$\mathrm{D}_{(\mathrm{t})}$ & 0,04184 & 0,006070 & $* * *$ \\
\hline AR(2) & 2,56 & & 0,01 \\
$\mathrm{AR}_{(3)}$ & 1,07 & & 0,284 \\
Hansen & 18,08 & & 0,054 \\
\hline
\end{tabular}

Notes: $\mathrm{ERA}_{\mathrm{it}}=$ Economic return on assets of the firm $i$ at the period $t, \mathrm{C}=$ Ownership concentration, $Y M_{i t}$ is a dummy which is equal to 1 if the age of the company is lower than the mean and zero otherwise, and $\mathrm{D}_{(\mathrm{t})}=$ Dummy of period t. AR $=$ Arellano and Bond test, Hansen $=$ Hansen test.

*** Significant at $1 \%$ level; ** Significant at $5 \%$ level; * Significant at $10 \%$ level.

\subsection{Insider Ownership and Corporate Operational Profitability}

Estimation results of the model that establishes a link between operational profitability and insider ownership (model 3) are summarized in Table 5. The coefficients of the columns I and II are all shown to be meaningful, validating a quadratic relationship between insider ownership and operational profitability. It is not possible, however, to support the cubic specification of the model with the values obtained when this specification is considered (see column III). The coefficients for $I O$ and $I O^{2}$, respectively negative and positive, constitute an management entrenchment effect and convergence of interests. For insider ownership values up to $79.10 \%$, operational profitability decreases, suggesting that insiders are less interested in the welfare of the other owners and that their greater security is more likely to entrench them. For higher values, the increases in insider ownership are translated into increased operational profitability, where the added incentives that managers/directors have to maximize the value can contribute to their increased participation. The results do not allow the cubic specification formulated in Hypothesis 3 to be validated; however, the coefficients of the variables $I O$ and $I O^{2}$ support a quadratic relationship between insider ownership and operational profitability. 
Table 5. Results of the estimation of the impact insider ownership on operational profitability

\begin{tabular}{|c|c|c|c|c|c|c|c|c|c|}
\hline & \multicolumn{9}{|c|}{ Insider ownership } \\
\hline & \multicolumn{3}{|c|}{$\begin{array}{c}\text { Linear } \\
\text { I }\end{array}$} & \multicolumn{3}{|c|}{$\begin{array}{c}\text { Squared } \\
\text { II }\end{array}$} & \multicolumn{3}{|c|}{$\begin{array}{r}\text { Cubic } \\
\text { III }\end{array}$} \\
\hline & Coef. & Std. Err. & $\mathrm{P}>|\mathrm{t}|$ & Coef. & Std. Err. & $\mathrm{P}>|\mathrm{t}|$ & Coef. & Std. Err. & $\mathrm{P}>|\mathrm{t}|$ \\
\hline \multicolumn{10}{|l|}{ ERA $_{i t}$} \\
\hline ERA $_{\mathrm{i}(\mathrm{t}-1)}$ & 0,36615 & 0,032749 & $* * *$ & 0,36706 & 0,032709 & $* * *$ & 0,36719 & 0,03271 & $* * *$ \\
\hline $\mathrm{IO}_{\text {it }}$ & $-0,00011$ & 0,000022 & $* * *$ & $-0,00038$ & 0,000086 & $* * *$ & $-0,00061$ & 0,00022 & $* * *$ \\
\hline $\mathrm{IO}^{2}{ }_{\mathrm{it}}$ & & & & $2,38 \mathrm{E}-06$ & 0,000001 & $* * *$ & $8,56 \mathrm{E}-06$ & 4,96E-06 & $*$ \\
\hline $\mathrm{IO}^{3}{ }_{\text {it }}$ & & & & & & & $-3,95 \mathrm{E}-08$ & $3,04 \mathrm{E}-08$ & \\
\hline$D_{(t-4)}$ & 0,05735 & 0,003467 & $* * *$ & 0,06094 & 0,004009 & $* * *$ & 0,06150 & 0,00413 & $* * *$ \\
\hline$D_{(t-3)}$ & 0,05452 & 0,003518 & $* * *$ & 0,05812 & 0,004056 & $* * *$ & 0,05867 & 0,00418 & $* * *$ \\
\hline$D_{(t-2)}$ & 0,05372 & 0,003549 & $* * *$ & 0,05735 & 0,004085 & $* * *$ & 0,05791 & 0,00421 & $* * *$ \\
\hline$D_{(t-1)}$ & 0,05712 & 0,003551 & $* * *$ & 0,06078 & 0,004090 & $* * *$ & 0,06135 & 0,00422 & $* * *$ \\
\hline $\mathrm{D}_{(\mathrm{t})}$ & 0,03791 & 0,003727 & $* * *$ & 0,04161 & 0,004267 & $* * *$ & 0,04217 & 0,00439 & $* * *$ \\
\hline $\operatorname{AR}(2)$ & 2,56 & & 0,010 & 2,57 & & 0,010 & 2,57 & & 0,010 \\
\hline $\begin{array}{l}\mathrm{AR}(3) \\
\text { Hansen }\end{array}$ & $\begin{array}{r}1,04 \\
15\end{array}$ & & $\begin{array}{l}0,299 \\
0,018\end{array}$ & $\begin{array}{l}1,03 \\
154\end{array}$ & & 0,303 & $\begin{array}{r}1,03 \\
1,43\end{array}$ & & 0,301 \\
\hline
\end{tabular}

Notes: $\mathrm{ERA}_{\mathrm{it}}=$ Economic return on assets of the firm $i$ at the period $t, \mathrm{IO}=$ Insider ownership, and $\mathrm{D}_{(\mathrm{t})}=$ Dummy of period t.

$\mathrm{AR}=$ Arellano and Bond test, Hansen $=$ Hansen test

*** Significant at $1 \%$ level; ** Significant at $5 \%$ level; * Significant at $10 \%$ level.

5.4 Operational Profitability and Ownership Concentration

Table 6 presents the estimation results of model 4. Analysis of these results shows a causal relationship between the operational profitability with one period lag and ownership concentration. The value of the operational profitability coefficient is positive and significant validating not only the relationship of reciprocity, but also the determinant role it has on ownership concentration. The results reveal the importance of operational profitability, namely in the previous period, on ownership concentration, as suggested by Hypothesis 4, which is consistent with previous empirical evidence (e.g., Thomsen, Pedersen, \& Kvist, 2006).

Table 6. Results of the estimation of the impact of operational profitability on ownership concentration on yield grounds

\begin{tabular}{lccl}
\hline & \multicolumn{3}{c}{ Total sample } \\
& Coef. & Std. Err. & $\mathrm{P}>|\mathrm{t}|$ \\
\hline $\mathrm{C}_{\mathrm{it}}$ & & & \\
$\mathrm{C}_{\mathrm{i}(\mathrm{t}-1)}$ & 0,05388 & 0,081832 & \\
$\mathrm{ERA}_{\mathrm{it}}$ & (dropped) & & \\
$\mathrm{ERA}_{\mathrm{i}(\mathrm{t}-1)}$ & 191,16210 & 77,098000 & $* *$ \\
$\mathrm{D}_{(\mathrm{t}-4)}$ & $-0,64643$ & 0,149352 & $* * *$ \\
$\mathrm{D}_{(\mathrm{t}-3)}$ & $-0,51151$ & 0,173992 & $* * *$ \\
$\mathrm{D}_{(\mathrm{t}-2)}$ & $-0,12561$ & 0,112239 & \\
$\mathrm{D}_{(\mathrm{t}-1)}$ & 0,69834 & 0,221077 & $* * *$ \\
\hline AR(2) & $-2,500$ & & 0,012 \\
$\mathrm{AR}(3)$ & $-0,380$ & & 0,701 \\
Hansen & 5,980 & & 0,112 \\
\hline
\end{tabular}

Notes: $\mathrm{ERA}_{\mathrm{it}}=$ Economic return on assets of the firm $i$ at the period $t, \mathrm{C}=$ Ownership concentration, and $\mathrm{D}_{(\mathrm{t})}=$ Dummy of period $t$.

$\mathrm{AR}=$ Arellano and Bond test, Hansen $=$ Hansen test.

*** Significant at $1 \%$ level; ** Significant at $5 \%$ level; * Significant at $10 \%$ level. 


\subsection{Operational Profitability and Insider Ownership}

The estimation results of model 5, which establishes a relationship between operational profitability and insider ownership, are found in Table 7. The coefficients of operational profitability (current and lagging by one period) are statistically significant, with a negative relationship with the insider ownership. The insider ownership held in the previous period is also a determinant of insider ownership at the current time. The inverse relationship between operational profitability and insider ownership suggests that - as a result of expropriation practices performed by the controlling owner and by allocating managerial/directorial positions to people appointed by him - operational profitability is not a sufficient incentive to induce greater participation by managers/directors in corporate ownership. The absence of a clear distinction between individual and corporate property, the propensity to give up, in the short run, income (safeguarding the business for future generations) and reduced professionalism of the management/administration can contribute to operational profitability not being considered an sufficiently relevant incentive for the participation of managers/directors in the ownership (Anderson \& Reeb, 2003, Wang, 2006, Arosa et al., 2010). The estimation results of the model and the negative coefficients of the $E R A_{i t}$ and $E R A_{i(t-1)}$ support Hypothesis 5, but with an opposite impact (negative) to what was formulated.

Table 7. Estimation of impact of operational profitability on insider ownership

\begin{tabular}{clll}
\hline & $\begin{array}{l}\text { Sample } \\
\text { Coef. }\end{array}$ & Std. Err. & $\mathrm{P}>|\mathrm{t}|$ \\
\hline $\mathrm{IO}_{\mathrm{it}}$ & & & \\
$\mathrm{IO}_{\mathrm{i}(\mathrm{t}-1)}$ & 0,14744 & 0,081506 & $*$ \\
$\mathrm{ERA}_{\mathrm{it}}$ & $-35,02412$ & 7,595487 & $* * *$ \\
$\mathrm{ERA}_{\mathrm{i}(\mathrm{t}-1)}$ & $-9,40107$ & 2,873151 & $* * *$ \\
$\mathrm{D}_{(\mathrm{t}-4)}$ & 5,98738 & 0,587962 & $* * *$ \\
$\mathrm{D}_{(\mathrm{t}-3)}$ & 5,35080 & 0,517579 & $* * *$ \\
$\mathrm{D}_{(\mathrm{t}-2)}$ & 3,78319 & 0,410201 & $* * *$ \\
$\mathrm{D}_{(\mathrm{t}-1)}$ & 3,20760 & 0,321417 & $* * *$ \\
\hline AR(2) & 0,81 & & 0,418 \\
$\mathrm{AR}(3)$ & $-1,18$ & & 0,239 \\
Hansen & 24,88 & & 0,024 \\
\hline
\end{tabular}

Notes: $\mathrm{ERA}_{\mathrm{it}}=$ Economic return on assets of the firm $i$ at the period $t, \mathrm{IO}=$ Insider ownership, and $\mathrm{D}_{(\mathrm{t})}=$ Dummy of period t. AR $=$ Arellano and Bond test, Hansen $=$ Hansen test.

*** Significant at $1 \%$ level; ** Significant at $5 \%$ level; * Significant at $10 \%$ level.

\subsection{Robustness Analysis}

The models proposed require a methodology that makes use of the instrumental variables as a mechanism to control the possible endogeneity of the explanatory variables. The best choice is a GMM estimator because it incorporates all of the others (Ogaki, 1993). Furthermore, GMM is particularly suitable for this study given the dynamic nature of the variables. Previous studies show that in the context of dynamic models, various estimation techniques generate biased estimators. Specifically, the ordinary least squares method (OLS) yields an overestimation of the parameters by virtue of the presence of individual endogeneity (Hsiao, 2003). Moreover, the estimators with centred variables (Wihin-groups) give rise to default values (Nickell, 1981). More recently, Alonso-Borrego and Arellano (1999) show that the first difference GMM estimators are subject to a problem of weak instruments. As a result Blundell and Bond (1998) propose the system GMM in the context of dynamic models.

To validate that the system GMM is the best suited to our study, we compared the results obtained (Equation 1) with this methodology with other estimation techniques. The results obtained are shown in Table 8. The lag ERA coefficient, using the reference estimation method (System GMM), is 0.36560 (column IV). As Hsiao (2003) suggests, the coefficient obtained by the OLS estimator, 0.64435 (column I) has a higher value. The value of the coefficient, estimated by Within-Groups, 0.13015 , is clearly inferior. Contrary to the OLS and the Within-groups, it is not possible to establish any specific relationship between the first difference GMM and the System GMM. As 
shown in Table 8 (Column III), the yield coefficient of the offset is 0.15562 , smaller than the coefficient obtained by the System GMM (0.36560).

Given the values obtained and according to the authors indicated, we can conclude that System GMM is the method which best serves the purposes of our work. Thus, all of the models were estimated using the System GMM. The methodology allows the endogeneity of the variables in the model to be controlled, with the inclusion of lags of the second and third period, lags $(2,3)$, as instruments in the equations in differences and with only one lag in the equations for levels, as suggested by Blundell and Bond (1998).

Tests were carried out to assess the quality of the specification models. Through Hansen's $J$ overidentification statistic, the selected instruments were validated, and the $A R$ (2) and $A R$ (3) statistics developed by Arellano and Bound (1991) revealed the absence of second-order correlation in the first residual differences; no problems were identified in the models.

Table 8. Results of model I with by use of different estimators

\begin{tabular}{|c|c|c|c|c|c|c|c|c|c|c|c|c|}
\hline & \multicolumn{3}{|c|}{$\begin{array}{c}\text { Ordinary least squares } \\
\text { estimator } \\
\text { I } \\
\end{array}$} & \multicolumn{3}{|c|}{$\begin{array}{c}\text { Within-groups estimator } \\
\text { II } \\
\end{array}$} & \multicolumn{3}{|c|}{$\begin{array}{c}\text { First difference GMM } \\
\text { III }\end{array}$} & \multicolumn{3}{|c|}{$\begin{array}{c}\text { System GMM } \\
\text { IV } \\
\end{array}$} \\
\hline & Coef. & Std. Err. & $\mathrm{P}>|\mathrm{t}|$ & Coef. & Std. Err. & $\mathrm{P}>|\mathrm{t}|$ & Coef. & Std. Err. & $\mathrm{P}>|\mathrm{t}|$ & Coef. & Std. Err. & $\mathrm{P}>|\mathrm{t}|$ \\
\hline \multicolumn{13}{|l|}{$\mathrm{ERA}_{\mathrm{it}}$} \\
\hline $\mathrm{ERA}_{\mathrm{i}(-1) \mathrm{t}}$ & 0,64435 & 0,022879 & $* * *$ & 0,13015 & 0,029984 & $* * *$ & 0,15562 & 0,054694 & $* * *$ & 0,36560 & 0,032750 & $* * *$ \\
\hline $\mathrm{C}_{\mathrm{it}}$ & $-0,00031$ & 0,000116 & $* * *$ & $-0,00048$ & 0,000241 & $* *$ & $-0,00030$ & 0,000218 & & $-0,00043$ & 0,000149 & $* * *$ \\
\hline $\mathrm{C}^{2}{ }_{\text {it }}$ & $2,22 \mathrm{E}-06$ & 0,000001 & $* * *$ & $3,37 \mathrm{E}-06$ & 0,000002 & $*$ & $1,68 \mathrm{E}-06$ & 0,000002 & & $3,16 \mathrm{E}-06$ & 0,000001 & $* * *$ \\
\hline $\mathrm{D}_{(\mathrm{t}-4)}$ & 0,01991 & 0,001492 & $* * *$ & (dropped) & & & 0,03865 & 0,006906 & $* * *$ & 0,06120 & 0,005929 & $* * *$ \\
\hline $\mathrm{D}_{(\mathrm{t}-3)}$ & 0,01666 & 0,001463 & $* * *$ & $-0,00227$ & 0,000976 & $* *$ & 0,02721 & 0,003480 & $* * *$ & 0,05856 & 0,005950 & $* * *$ \\
\hline $\mathrm{D}_{(\mathrm{t}-2)}$ & 0,01574 & 0,001440 & $* * *$ & $-0,00435$ & 0,000996 & $* * *$ & 0,02062 & 0,002864 & $* * *$ & 0,05783 & 0,005973 & $* * *$ \\
\hline $\mathrm{D}_{(\mathrm{t}-1)}$ & 0,02012 & 0,001456 & $* * *$ & $-0,00116$ & 0,001090 & & 0,02203 & 0,002552 & $* * *$ & 0,06127 & 0,006014 & $* * *$ \\
\hline $\mathrm{D}_{(\mathrm{t})}$ & (dropped) & & & $-0,01991$ & 0,001476 & $* * *$ & & & & 0,04235 & 0,006145 & $* * *$ \\
\hline $\mathrm{AR}(2)$ in first dif:: $Z=$ & & & & & & & 1,610 & & 0,108 & 2,540 & & 0,011 \\
\hline$A R(3)$ in first dif.: $Z=$ & & & & & & & 1,250 & & 0,210 & 1,040 & & 0,297 \\
\hline Hansen test: Chi2 = & & & & & & & 1,220 & & 0,543 & 17,850 & & 0,022 \\
\hline
\end{tabular}

Notes: $\mathrm{ERA}_{\mathrm{it}}=$ Economic return on assets of the firm $i$ at the period $t, \mathrm{C}=\mathrm{C}=$ Ownership concentration, and $\mathrm{D}_{(\mathrm{t})}=$ Dummy of period t.

*** Significant at $1 \%$ level; ** Significant at $5 \%$ level; * Significant at $10 \%$ level.

\section{Conclusion}

In this study we analyzed the relationship between operational profitability, ownership concentration and insider ownership, extending the previous literature in this area, highlighting their endogenous nature and dynamics. The control of unobserved heterogeneity and individual endogeneity, provided by panel data the methodology allows role of ownership concentration and insider ownership to be evaluated as control mechanisms within the governance of small firms.

To achieve this goal, several steps were taken. First, we analyzed the relationship between ownership concentration and corporate operational profitability through a quadratic specification, which is validated for the companies under study and for the subsamples generated from the criteria of size, age and nature of owership. When we segment the sample by the nature of ownership, the empirical evidence shows that the relationship is valid only for family businesses, in line with the potential benefits associated with these companies. The results are in line with those obtained by Hu and Izumida (2008) for Japanese family businesses. They confirm the relationship Arosa et al. (2010) formulated and which we were unable validate it in the context of unlisted Spanish companies and suggest a U-shaped relationship between ownership concentration and performance - the inverse of that obtained by Miguel $e t$ 
al. (2004) on listed companies context. Nevertheless, for family businesses, the relationship differs depending on age - young companies show a negative relationship between ownership concentration and operational profitability for low levels of control rights, so that the expropriation hypothesis prevails; and they show a positive relationship for high levels of ownership concentration, as a consequence of the supervision hypothesis.

The next step reinforces the role of ownership concentration on operational profitability, when this is moderated by firm age. During the third step, the results confirm the management entrenchment effect and the convergence of interests in the relationship established between the insider ownership and operational profitability. They do not validate, however, the cubic relationship established by Miguel et al. (2004).

The inverse causality relationship tested in the fourth and fifth steps brings new evidence to the existing literature. The results are in line with the findings of studies conducted in the United States (e.g., Cho, 1998 and Demsetz \& Villalonga, 2001) and validate the relationship not identified in Hu and Izumida (2008) and Arosa et al. (2010) on samples of similar companies to those used in our study.

Additional research is needed, in our view, to overcome some constraints found in this work. Firstly it is very difficult to carry out a comparative study between different institutional contexts due to the absence/scarcity of databases with unlisted companies, which allow the role of ownership concentration in disciplining managers/directors and business performance to be assessed in the absence of effective external control mechanisms. Additionally, the lack of data also prevented us to make a clear distinction between the company's founder and other members, to assess the relevance of the 'generation effect'.

\section{References}

Agrawal, A., \& Mandelker, N. (1990). Large shareholders and the monitiring of management: the case of antitakover charter amendments. Journal of Finance and Quantitativa Analysis, 25(2), 143-161. http://dx.doi.org/10.2307/2330821

Alonso-Borrego, C., \& Arellano, M. (1999). Symmetrically normalized instrumental-variable estimation using panel data. Journal of. Business and Economic Statistc., 17(1), 36-49. http://dx.doi.org/10.1080/07350015.1999.10524795

Anderson, R. C., \& Reeb, D. M. (2003). Fouding-Family ownership and firm performance: Evidence from the S\&P 500. The Journal Finance, 58(3), 1301-1328. http://dx.doi.org/10.1111/1540-6261.00567

Aras, G., Aybars, A., \& Kutlu, O. (2010). Managing corporate performance: Investigating the relationship between corporate social responsibility and financial performance in emerging markets. International Journal of Productivity and Performance Management, 59(3), 229-254. http://dx.doi.org/10.1108/17410401011023573

Arellano, M., \& Bond, S. (1991). Some tests of specification for panel data: Monte Carlo evidence and an application to employment equations. Review of Economic Studies, 58(2), 277-297. http://dx.doi.org/10.2307/2297968

Arosa, B., Iturralde, T., \& Maseda, A. (2010). Ownership structure and firm performance in non-listed firms: Evidence from Spain. Journal of Family Business Strategy, 1(2), 88-96. http://dx.doi.org/10.1016/j.jfbs.2010.03.001

Baraontini, R., \& Caprio, L. (2006). The effect of family control on the firm value and performance: Evidence from continental Europe. European Financial Manegement, 12(5), 689-723. http://dx.doi.org/10.1111/j.1468-036X.2006.00273.x

Bebchuk, A. Cohen, \& Ferrell, A. (2009). What matters in corporate governance?. The Review of Financial Studies, 22(2), 783-827. http://dx.doi.org/10.1093/rfs/hhn099

Behr, P., Norden, L., \& Noth, F. (2013). Financial constraints of private firms and bank lending behaviour. Journal of Banking \& Finance, 37(9), 3472-3485. http://dx.doi.org/10.1016/j.jbankfin.2013.05.018

Bennedsen, M., Nielsen, K., Pérez-González, F., \& Wolfenzon, D. (2007). Inside the family firm: The role of families in succession decisions and performance. The Quarterly Journal of Economics, 122(2), 647-691. http://dx.doi.org/10.1162/qjec.122.2.647

Berger, P., Ofek, E., \& Yermack, D. (1997). Managerial entrenchment and capital structure decisions. The Journal of Finance, 52(4), 1411-1438. http://dx.doi.org/10.1111/j.1540-6261.1997.tb01115.x

Blundell, R., \& Bond, S. (1998). Initial conditions and moment restrictions in dynamic panel data models. Journal of Econometrics, 87(1), 115-144. http://dx.doi.org/10.1016/S0304-4076(98)00009-8 
Castelli, A., Dwyer, P., \& Hasan, I. (2012). Bank relationships and firms' financial performance: The Italian experience. European Financial $\quad$ Management, $\quad$ 18(1), http://dx.doi.org/10.1111/j.1468-036X.2009.00531.x

Cho, M. (1998). Ownership structure, investment, and the corporate value: An empirical analysis. Journal of Financial Economics, 47(1), 103-121. http://dx.doi.org/10.1016/S0304-405X(97)00039-1

Chrisman, J., Chua, J., \& Sharma, P. (2005). Trends and directions in the development of a strategic management theory of the family firm. Entrepreneurship Theory and Practice, 29(5), 555-576. http://dx.doi.org/10.1111/j.1540-6520.2005.00098.x

$\mathrm{Chu}$, W. (2011). Family ownership and firm performance: Influence of family management, family control, and firm size. Asia Pacific Journal of Management, 28(4), 833-851. http://dx.doi.org/10.1007/s10490-009-9180-1

Chua, H., Chrisman, J., \& Sharma, P. (2003). Sucession and nonsuccession concerns of family firms and agency relationship with nonfamily managers. Family Business Review, 16(2), 89-107. http://dx.doi.org/10.1111/j.1741-6248.2003.00089.x

Costa, J. (1998). O impacto do entrincheiramento no earnings management. Master dissertation. Oporto University, Portugal, 39-49.

Cronqvist, H., \& Nilsson, M. (2003). Agency cost of controlling minority shareholders. Journal of Financial \& Quantitative Analysis, 8(4), 695-719. http://dx.doi.org/10.2307/4126740

David, R. (2006). How to do xtabond2: An Introduction to "Difference" and "System" GMM in Stata. Center of Global Development, Working paper number 103.

Del Brio, B., Maia-Ramires, L., \& De Miguel, A. (2011). Ownership structure and diversification in a scenario of weak shareholder protection. Applied Economics, 43(29), 4537-4547. http://dx.doi.org/10.1080/00036846.2010.491472

Demsetz, H., \& Lehn, K. (1985). The structure of corporate ownership: cause and consequences. Journal of Political Economics, 93(6), 1155-1177.

Demsetz, H. (1983). The structure of ownership and the theory of the firm. Journal of Political Economics, 26(2), 375-390.

Demsetz, H., \& Villalonga, B. (2001). Ownership structure and corporate performance. Journal of Corporate Finance, 7(3), 209-233. http://dx.doi.org/10.1016/S0929-1199(01)00020-7.

Denis, D. (1994). Majority owner-managers and organizational efficiency. Journal of Corporate Finance, 1(1), 91-118. http://dx.doi.org/10.1016/0929-1199(94)90011-6

Fama, E., \& Jensen, M.C. (1983a). Separation of ownership and control. Journal of Law and Economics, 26(2), 301-325.

Fama, E., \& Jensen, M.C. (1983b). Agency problems and residual claims. Journal of Law and Economics, 26(June), 327-349.

Gaver, J., \& Gaver, K. (1993). Additional evidence on the association between the investment opportunity set and corporate financing, dividend, and compensation policies. Journal of Accounting and Economics, 16(1-3), 125-160. http://dx.doi.org/10.1016/0165-4101(93)90007-3

Gedajlovic, E., \& Shapiro, D. (1998). Management and ownership effects: evidence from five countries. Strategic Management Journal, 19(6), 533-553.

Goddard, J., \& Wilson, J. (1999). The persistence of profitt: a new empirical interpretation. International Journal of Industrial Organization, 17(5), 663-687. http://dx.doi.org/10.1016/S0167-7187(97)00055-6

Gomez-Mejia, L., Nunez-Nickel, M., \& Gutierrez, I. (2001). The role of family ties in agency contracts. Academy of Management Journal, 44(1), 81-95. http://dx.doi.org/10.2307/3069338

Gorton, G., \& Schmidt, A. (2000). Universal Banking and the performance of German firms. Journal of Financial Economics, 58(1-2), 29-80. http://dx.doi.org/10.1016/S0304-405X(00)00066-0

Greenaway, D., Guariglia, A., \& Yu, Z. (2012). The more the better? Foreign ownership and corporate performance in China. The European Journal of Finance, June(1-22). http://dx.doi.org/10.1080/1351847X.2012.671785 
Grossman, S., \& Hart, O. (1986). The Costs and Benefits of Ownership: A Theory of Vertical and Lateral Integrat. Journal of Political Economy, 94(4), 691-719.

Hill, C., \& Snell, S. (1988). External control, corporate strategy, and firm performance in research-intensive industries. Strategic Management Journal, 9(6), 577-590. http://dx.doi.org/10.1002/smj.4250090605

Himmelberg, P., Glenn Hubbard, R., \& Palia, D. (1999). Understanding the determinants of managerial ownership and the link between ownership and performance. Journal of Financial Economics, 53(3), 353-384. http://dx.doi.org/10.1016/S0304-405X(99)00025-2

Holderness, C. (2003). A Survey of Blockholders and Corporate Control. Economic Policy Review, 9(1), 51-64.

Hsiao, C. (2003). Analysis of panel data. Cambridge University Press, Cambridge, United Kingdom.

Hu, Y., \& Izumida, S. (2008). Ownership concentration and corporate performance: A causal analysis with japaneses panel data. Corporate Governance An International Review, 16(4), 342-358. http://dx.doi.org/10.1111/j.1467-8683.2008.00690.x

Jensen, M. C. (1993). The modem industrial revolution, exit, and the failure of internal control systems. The Journal of Finance, 6(4), 4-23. http://dx.doi.org/10.1111/j.1540-6261.1993.tb04022.x

Jensen, M. C., \& Meckling, W. H. (1976). Theory of the firm: managerial behaviour, agency cost and ownership structure. Journal of Financal Economic, 3(4), 305-360. http://dx.doi.org/10.1016/0304-405X(76)90026-X

Kaplan, S., \& Minton, B. (1994). Appointements of outsiders to Japanese. Determinants and implications for $\begin{array}{lllll}\text { managements. Journal of } & \text { Finance }\end{array}$ http://dx.doi.org/10.1016/0304-405X(94)90025-6

La Porta, R., Florencio A., \& Shleifer A. (1999). Corporate ownership around the World. The Journal of Finance, 54(2), 471-518. http://dx.doi.org/10.1111/0022-1082.00115

La Porta, R., López, F., Shleifer, A., \& Vishny, R. (1998). Law and Finance. Journal of Political Economy, 106(6), 1113-1155.

La Porta, R., López, F., Shleifer, A., \& Vishny, R. (2000). Agency problems and dividend policies around the world. The Journal of Finance, 55(1), 1-33. http://dx.doi.org/10.1111/0022-1082.00199

Leech, D., \& Leahy, J. (1991). Ownership structure, control type classsification and the performance of large British companies. Economic Journal, 101(409), 1418-1437.

Lehmann, E., \& Weigand, J. (2000). Does de governed corpotation perform better? Governance structures and corporate performance in Germany. European Finance Review, 4(2), 157-195. http://dx.doi.org/10.1023/A:1009896709767

Lisboa, I. (2007). Does ownership influence performance? Evidence from Europe. Master Dissertation, ISCTE, Portugal, 23-38.

Loderer, C., \& Martin, K. (1997). Executive stock ownership and performance: tracking faint traces. Journal of Financial Economics, 45(2), 223-255. http://dx.doi.org/10.1016/S0304-405X(97)00017-2

Margaritis, D., \& Psillaki, M. (2010). Capital structure, equity ownership and firm performance. Journal of Banking \& Finance, 34(3), 621-632. http://dx.doi.org/10.1016/j.jbankfin.2009.08.023

Martikainen, M., Nikkinen, J., \& Vähämaa, S. (2009). Production functionsa nd productivity of family firms: Evidence from the S\&P 500. The Quarterly Review of Economics and Finance, 49(2), 295-307. http://dx.doi.org/10.1016/j.qref.2007.11.001

Masulis, R., Wang, C., \& Xie, F. (2012). Globalizing the boardroom - The effects of foreign directors on corporate governance and firm performance. Journal of Accounting and Economics, 53(3), 527-554. http://dx.doi.org/10.1016/j.jacceco.2011.12.003

Mehran, H. (1995). Executive compensation structure, ownership and firm performance. Journal of Financial Economics, 39(2), 163-184. http://dx.doi.org/10.1016/0304-405X(94)00809-F

Miguel, A., Pindado, J., \& Torre, L. (2004). Ownership structure and firm value: new evidence from the Spanish corporate governance system. Strategic Management Journal, 25(12), 1199-1207. http://dx.doi.org/10.1002/smj.430 
Miller, D., \& Le Breton-Miller, I. (2006). Family governance and firm performance: Agency, stewardship, and capabilities. Family Business Review, 19(1), 73-87. http://dx.doi.org/10.1111/j.1741-6248.2006.00063.x

Morck, R., Nakamura, M., \& Shivdasani, A. (2000). Banks, ownership structure and firm value in Japan. Journal of Business, 73(4), 539-567.

Mudambi, R., \& Nicosia, C. (1998). Ownership struture and firm performance: evidence from U.K. financial services industry. Applied Financial Economics, 8(2), 175-180. http://dx.doi.org/10.1080/096031098333159

Nickell, S. (1981). Biases in dynamic models with fixed effects. Econometria, 49(6), 1417-1426.

Ogaki, M. (1993). Generalized method of moments: econometric applications. In Maddala, G.S., Rao, C.R., \& Vinod H.D. (Eds.), Handbook of Statistics (pp. 455-488). North Holland, Amsterdam.

Oswald, S., \& Jahera, Jr. (1991). The influence of ownership on performance: an empirical study. Strategic Management Journal, 12(4), 321-326. http://dx.doi.org/10.1002/smj.4250120407

Pegels, C., Song, Y., \& Yong, B. (2000). Management heterogeneity, competitive interaction groups, and firm performance. Strategic Management Journal, 21(9), 911-923. http://dx.doi.org/10.1002/1097-0266(200009)

Pindado, J., Requejo, I., \& De la Torre, C. (2011). Family control and investment-cash sensitivity: Empirical evidence from the Euro zone. Journal of Corporate Finance, 17(5), 1389-1409. http://dx.doi.org/10.1016/j.jcorpfin.2011.07.003

Schulze, W., Lubatkin, M., \& Dino, R. (2002). Altruism, agency, and competitiveness of family firms. Managerial and Decision Economics, 23(4-5), 247-259. http://dx.doi.org/10.1002/mde.1064

Schulze, W., Lubatkin, M., Dino, R., \& Buchholtz, A. (2001). Agency relationship in family firms: theory and evidence. Organization Science, 12(2), 99-116. http://dx.doi.org/10.1287/orsc.12.2.99.10114

Sharmaa, P., Hoyb, F., Astrachanc, J., \& Koiranen, M. (2007). The practice-driven evolution of family business educacion. Journal of Business Research, 60(10), 1012-1021. http://dx.doi.org/10.1016/j.jbusres.2006.12.010

Shleifer, A., \& Vishny, R. (1986). Large shareholders and corporate control. Journal of Political Economy, 94(3), 461-488.

Shleifer, A., \& Vishny, R. (1997). A survey of corporate governance. The Journal of Finance, 52(2), 737-783. http://dx.doi.org/10.1111/j.1540-6261.1997.tb04820.x

Thomsen, S., \& Pedersen, T. (2000). Ownership structure and economic performnce in the largest European $\begin{array}{lllll}\text { companies. } & \text { Strategic }\end{array}$ http://dx.doi.org/10.1002/(SICI)1097-0266(200006)

Thomsen, S., Pedersen, T., \& Kvist, K. (2006). Blockholder ownership: Effects on firm value in market and control based governance suystem. Journal of Corporate Finance. 12(2), 246-269. http://dx.doi.org/10.1016/j.jcorpfin.2005.03.001

Villalonga, B., \& Amit, R. (2006). How do family ownership, control and management affect firm value?. Journal of Financial Economics, 80(2), 385-417. http://dx.doi.org/10.1016/j.jfineco.2004.12.005

Wang, D. (2006). Founding family ownership and earnings quality. Journal of Accounting Research, 44(3), 619-656. http://dx.doi.org/10.1111/j.1475-679X.2006.00213.x

Wang, Z., \& Sarkis, J. (2013). Investigating the relationship of sustainable supply chain management with corporate financial performance. International Journal of Productivity and Performance Management, 62(8), 871-888. http://dx.doi.org/10.1108/IJPPM-03-2013-0033

Westhead, P., \& Howorth, C. (2006). Ownership and management issues associated with family firm performance and company objectives. Family Business Revie, 19(4), 301-316. 10.1111/j.1741-6248.2006.00077.x

Wu, J., Xu, D., \& Phan, H. (2011). The effects of ownership concentration and corporate debt on corporate divestitures in Chinese listed firms. Asia Pacific Journal of Management, 28(1), 95-114. 10.1007/s10490-010-9208-6

Zhou, X. (2001). Understanding the determinants of managerial ownership and the link between ownership and $\begin{array}{llll}\text { performance. Journal of } & \text { Financial }\end{array}$ http://dx.doi.org/10.1016/S0304-405X(01)00085-X 